Article

\title{
DMOs and Rural Tourism: A Stakeholder Analysis the Case of Tucker County, West Virginia
}

\author{
Doug Arbogast*, Jinyang Deng and Kudzayi Maumbe \\ Recreation, Parks \& Tourism Resources Program, Division of Forestry and Natural Resources, \\ West Virginia University, Morgantown, WV 26505, USA; Jinyang.deng@mail.wvu.edu (J.D.); \\ Kudzayi.maumbe@mail.wvu.edu (K.M.) \\ * Correspondence: Doug.arbogast@mail.wvu.edu; Tel.: +1-304-293-8686
}

Received: 31 August 2017; Accepted: 26 September 2017; Published: 10 October 2017

\begin{abstract}
Rural destination management organizations (DMOs) are faced with considerable challenges as they attempt to promote economic prosperity through tourism. This study sought to identify rural destination management challenges in Tucker County, West Virginia; identify the roles and activities of the destinations DMOs in addressing these challenges; and develop a perceived destination management framework. DMO challenges include maintaining authenticity and sense of place; economic diversification; seasonality, low wage jobs, and lack of employees; connecting resorts to small businesses and communities; and establishing a common vision, identity, and coordination of activities. While the majority of tourism literature calls for DMOs to play a dual marketing and management role, this paper makes an important contribution by identifying the need for a Convention and Visitors Bureau and a separate organization with a specific mission to sustainably develop and manage tourism and coordinate activities of the stakeholder network.
\end{abstract}

Keywords: rural tourism; destination management; DMO

\section{Introduction}

Rural destination management organizations (DMOs) are faced with considerable challenges as they attempt to promote economic prosperity through tourism. These challenges often include managing growth while maintaining a sense of place, managing multiple objectives, limited funding for marketing and development, and limited capacity. Rural tourism has failed to develop a destination management culture that can cope with these challenges and the decentralized, multi-player, multi-stakeholder nature of the rural tourism business and its essential links to the conservation and economic management of rural areas [1]. This study sought to identify the challenges rural DMOs face as well as the appropriate role(s) of a rural DMO.

Funding for DMO activities in many destinations comes from accommodations taxes, which has been the most significant policy to affect rural tourism development in the USA to date providing destinations with enough revenue based funding to create Convention and Visitors Bureaus (CVBs) [2]. These CVBs are often the primary and sometimes sole DMO in many destinations. Since the primary funding source for CVBs comes from the "bed" tax, most small town CVBs often view their role as helping those businesses that collect the tax, e.g., putting "heads on beds", and not responsible for issues regarding tourism development [2].

According to some authors, the DMO is a marketing organization with the primary purpose to drive business to the destination [3], however, others advocate the transition of the " $\mathrm{M}$ " in DMO to refer to "management" rather than "marketing" because the role of DMOs has strengthened and spread as destinations have attempted to play a more proactive role in fostering and managing the benefits of tourism development [4]. Some authors recognize that marketing remains the principal purview of DMOs, however, there is a shift towards recognizing that the role of the DMO goes well beyond 
marketing to include other activities that are important to the success of tourism in a destination from a competitive and sustainable perspective $[3,5]$. Other authors argue that very few DMOs have either the mandate or resources to effectively manage their destination and that this will depend upon the precise legislative or political framework established to guide each DMO [6].

Tucker County, West Virginia can be considered to be in the development stage of the Tourism Lifecycle Model [7]. Destinations are often most vulnerable in the development stage where effective destination marketing and management is most critical to sustain growth while addressing resident concerns from growth issues and establishing guidelines for resource stewardship and sustainability [7]. The specific objectives of this study were to: (1) identify rural destination marketing and management challenges in Tucker County, WV; (2) identify the roles and activities of the destinations DMOs in addressing these challenges; and (3) develop a perceived destination management framework for addressing these challenges.

\section{Theoretical Framework}

The responsibilities of DMOs should include both an "external destination marketing" (EDM) function and an "internal destination development" (IDD) function [8]. The EDM function is meant to include all activities aimed at attracting visitors to the destination (see Table 1). These activities have an external orientation in that their aim is to influence the actions of persons outside the destination.

Internal Destination Development (IDD) activities are described as encompassing all other forms of activity (apart from marketing) undertaken by DMOs to develop and maintain tourism in the destination (see Table 1). The function of destination development is internal in that the activities are aimed at initiatives internal to the destination. An important assessment of the DMO ability to foster IDD will be directly related to the number and quality of relationships with tourism destination stakeholders and to conduct network analyses to determine the strength of the DMO's position (centrality) in the network vis-à-vis the density of the network [8]. Based on a sound core competency of stakeholder coordination, the DMO must establish a foundation for its IDD efforts by providing sound visitor management and information/research. From this foundation it is possible to develop the other dimensions of IDD (Quality of the Visitor Experience, Human Resources Development, Finance and Venture Capital, Resource Stewardship, and Crisis Management) that may be implemented by other stakeholders rather than the DMO directly (see Figure 1).

Table 1. Summary of the activities of the DMO categorized as either EDM or IDD.

\begin{tabular}{cccc}
\hline \multicolumn{2}{c}{ External Destination Marketing Activities } & \multicolumn{2}{c}{ Internal Destination Development Activities } \\
\hline Web Marketing & $\mathrm{e}_{1}$ & Visitor Management & $\mathrm{i}_{1}$ \\
Events, Conferences and Festivals & $\mathrm{e}_{2}$ & Information/Research & $\mathrm{i}_{2}$ \\
Cooperative Programs & $\mathrm{e}_{3}$ & Coordinating Tourism Stakeholders & $\mathrm{i}_{3}$ \\
Direct Mail & $\mathrm{e}_{4}$ & Crisis Management & $\mathrm{i}_{4}$ \\
Direct Sales & $\mathrm{e}_{5}$ & Human Resources Development & $\mathrm{i}_{5}$ \\
Sales Blitzes & $\mathrm{e}_{6}$ & Finance and Venture Capital & $\mathrm{i}_{6}$ \\
Trade Shows & $\mathrm{e}_{7}$ & Resource Stewardship & $\mathrm{i}_{7}$ \\
Advertising & $\mathrm{e}_{8}$ & Quality of the Visitor Experience & $\mathrm{i}_{8}$ \\
Familiarization Tours & $\mathrm{e}_{9}$ & & \\
Publications and Brochures & $\mathrm{e}_{0}$ & & \\
\hline
\end{tabular}

A two-dimensional graph (see Figure 2) was produced with the vertical axis representing the DMO efforts in IDD and the horizontal axis denoting the DMO efforts in EDM. The position of the $\mathrm{DMO}$ in the model is the combined result of the interaction of its efforts on these two dimensions and therefore reflective of its effort in managing the destination. Greater efforts on either dimension will lead to an enlargement of the DMO's total efforts to comprehensively manage the destination. The assumption is that the DMO may be able to increase its resources to allow it to increase its efforts on one function. It is also possible that the DMO might not increase total effort but rather 
redistribute effort from one function to another to achieve more of a balanced approach to managing the destination [8].

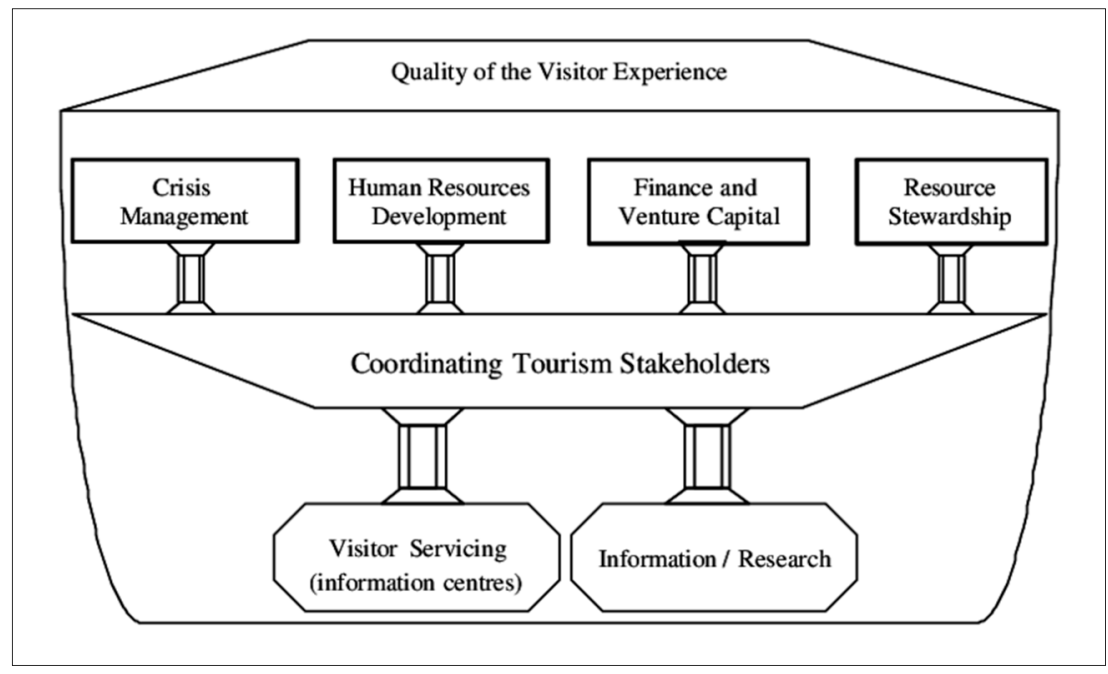

Figure 1. Internal Destination Development Activities [8]; with permission from authors.

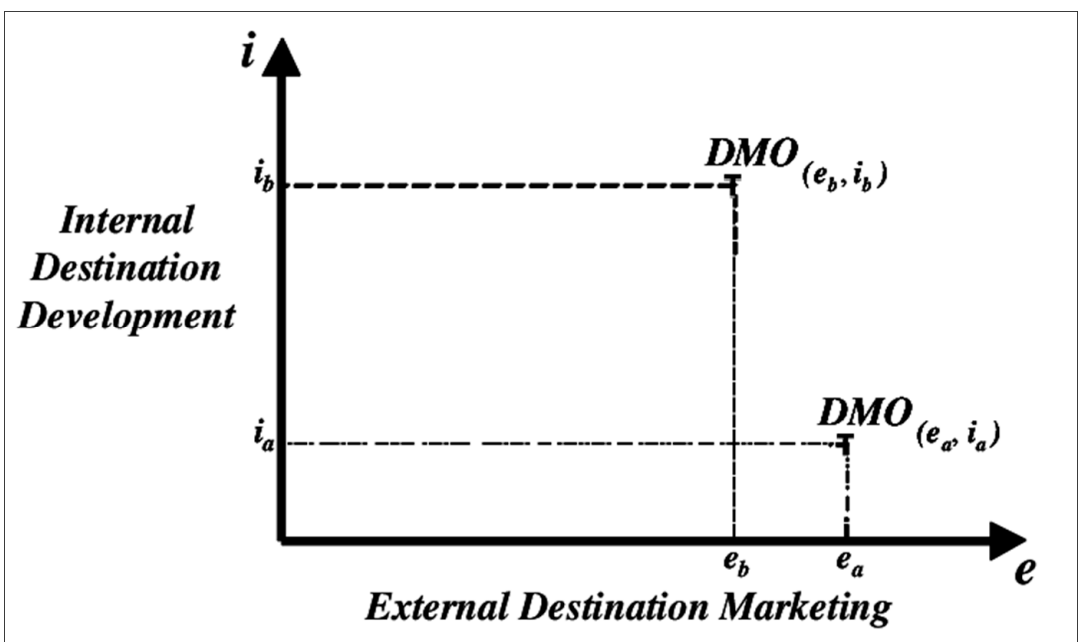

Figure 2. Descriptive model of destination management in terms of DMO efforts in Internal Destination Development and External Destination Marketing [8]; with permission from authors.

The authors suggest that the model may be used by destination marketers or managers to perform a destination audit, whereby the DMO compares the activities outlined in the model to what they currently do and search for other organizations throughout the community that may partially or fully perform (or potentially perform) other activities since each DMO must assess its environment and select the most appropriate set of activities relative to its primary purpose and resources [8].

\section{Literature Review}

While debate continues about the percentage of time and resources DMOs should allocate to marketing and management roles, studies have been conducted to examine specific challenges and success factors facing DMOs in rural destinations in an attempt to help guide them toward the most effective utilization of limited time and resources. Factors to achieve success in sustainable rural tourism include a complete tourism package, good community leadership, support and participation of local government, sufficient funds for tourism development, strategic planning, coordination 
and cooperation between businesspersons and local leadership, coordination and cooperation between rural tourism entrepreneurs, information and technical assistance, good convention and visitors bureaus, and widespread community support for tourism [9]. The University of Minnesota Extension Service identified five core values for sustainable community tourism development including maintaining authenticity and a sense of place, providing a quality experience, economic diversification, transforming obstacles to opportunities, and shared benefits and local control [10]. A study to determine potential tourism centerpieces for the Blue Ridge Heritage Area elicited the following important values to guide the project: authenticity, sustainability, respect, positive economic impact, political sensitivities, and target markets that minimize negative tourism impact and appreciate the uniqueness of the region [11]. Factors unique to DMO success include supplier relations, effective management, strategic planning, organizational focus and drive, proper funding, and quality personnel since, according to the authors, "If the DMO does not provide leadership and direction for tourism development in the destination, who will" [12]?

Challenges on the development of agrotourism in Cyprus include lack of support, lack of training, lack of local facilities/amenities, low occupancy levels, ineffective marketing, and the dominance of mass tourism operators as major challenges concluding that long-term financial and technical support is essential if tourism is to play an effective rural development role [13]. Additional studies in rural areas have determined that the quality of products and services must match tourists demands and expectations, thus, the total product package must be sufficient to attract and keep tourists, offering suitable opportunities for spending [14]; government subsidies may be required to maintain the social benefits of diversification into tourism [15]; and agricultural values and guest-service values are frequently incompatible [16].

The challenge rural areas face in balancing tourism growth with maintaining authenticity and sense of place has been noted in literature. The development of sustainable rural tourism has the potential to help secure the economic viability of rural communities and activities, which consequently can help maintain the special qualities of the countryside [17]. Part of the appeal of rural tourism is the fact that more people are living in urban areas, and in these urban areas feel that they are losing their cultural identities and individuality [18]. As destinations develop and cater to larger numbers of Psychocentrics they become increasingly commercialized over time thereby losing their authenticity and in turn "carrying with it the potential seeds of its own destruction" [19]. The New Tourism seeks to develop within each community a sensitivity to its unique heritage and environment, the resources giving a locality its special sense of place [20].

Destination management involves establishing goals, making choices and balancing trade-offs with an overall vision for the destination in mind and tourism resources are likely to be used more effectively when the different modes of deployment share a common view regarding a destination's strategy for tourism development [4]. However, challenges arise because a destination strives to achieve multiple goals, involves many different stakeholders, often lacks a focal organization that is able to see events from a bird's-eye view, and also faces difficulties gathering the disparate information required to assess its performance [4]. Exchange of information, use of synergies and coordination of action are supposed to positively affect destination development and are considered to be the building blocks for innovation and a versatile competitive base [21].

Unmanaged tourism, causing increased levels of competition between and within communities and relatives and subsequent social tensions, was viewed as a significant challenge for sustainable tourism in the Annapurna Conservation Area as was the dangers of unplanned tourism that puts increased pressures on natural resource usage. Therefore, for sustainable tourism development to be successful, long-term partnerships between different stakeholders are essential [22]. There is greater potential of sustaining ecotourism at any destination if all stakeholders are represented via networks and public private partnerships within and between sectors [23]. Strategies identified to improve networks and public private partnerships included forming more ecotourism advocacy groups, involving local community members, business and service providers, government agencies, 
and researchers and academician in managing ecotourism, involving stakeholders at the local level, and establishing networks for the interests of stakeholders [23].

A study of DMOs reform in Switzerland calls for a change from the traditional approach of looking at the destination and DMOs to a new paradigm where the level of discussion is not one territory but a productive flow of visitors with the destination's own competitive position, development phase, and specific organizations, actors, and institutions playing a duly active role [24]. Thus, the organization gradually changes, because of added, revised, or removed mandates [24]. A study in New Zealand sought to explain why structural differences occur within destination management identifying that no single model exists and the extent to which statutory functions incorporating aspects of destination management outside of marketing and promotion varying considerably [25]. The study concluded that there was not a lot of evidence to show that destination management is being carried out as an explicitly higher level function with a concerted effort to integrate all relevant functions in the coordinated fashion encouraged by the World Tourism Organization [25].

\section{Methods}

\subsection{Study Area}

Tucker County, West Virginia, is a rural county located in the Potomac Highlands region of the state (see Figure 3). With a population of 6966 in 2015, it is West Virginia's second-least populous county [26]. The county's economy boomed along with most of the state in the late 1800s and early 1900s fueled by the coal and timber industries attracting a population of close to 20,000 residents. These resources were largely exhausted by the mid-1950s forcing the industries to leave taking with them the jobs that attracted the residents causing the population to drop precipitously. The median household income in Tucker County in 2015 was $\$ 40,533$ while the median household income in the U.S. in 2015 was $\$ 56,516$ [26]. Today, due to more sustainable land management practices, Tucker County is a four-season tourism destination. Visitors contributed $\$ 42$ million in direct spending to the county's economy in 2013 providing 700 jobs [27]. Visitor attractions include outdoor recreation on federal and state lands including the Monongahela National Forest, Canaan Valley and Blackwater Falls State Parks, Canaan Valley National Wildlife Refuge, and Dolly Sods Wilderness Area; downhill and cross country skiing; the communities of Thomas, Davis, and Parsons; a rich heritage of coal mining and timbering; and art galleries and live music. After many years of planning and construction, Corridor $\mathrm{H}$ was recently completed providing direct highway access from major metropolitan areas.

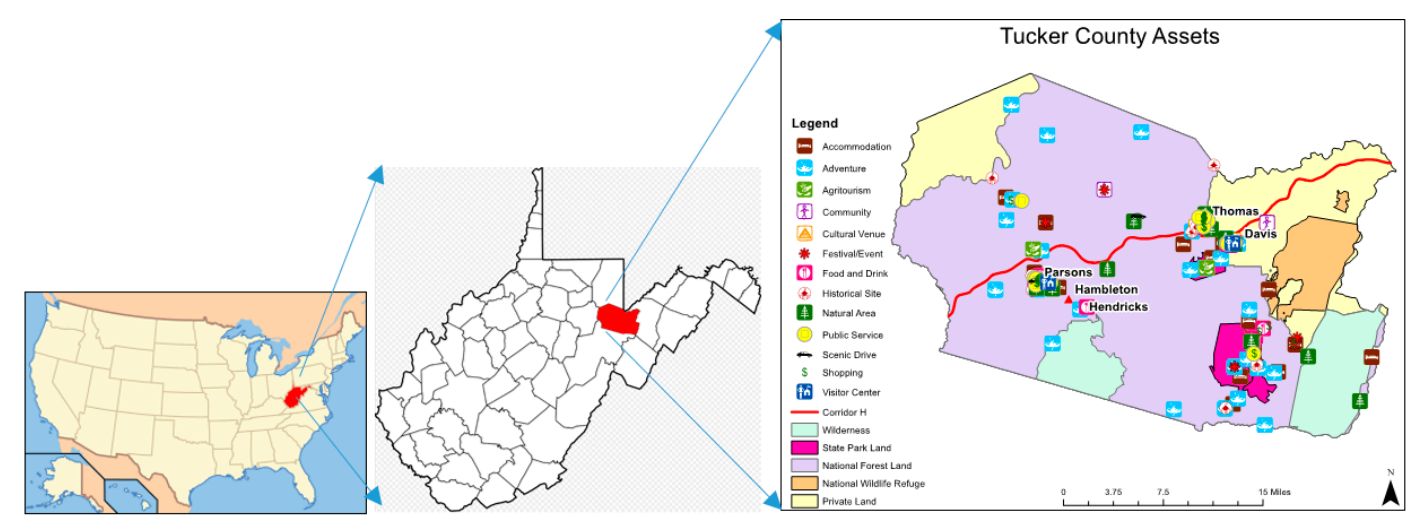

Figure 3. Tucker County, West Virginia.

The combination of outdoor recreation, art, music, and small towns make Tucker County a unique destination. One local resident described it as, "there's a vibe here that people pick up on. It's that vibe that attracts the kind of people that come here, it's just a deep-rooted kind of energy and it's developed this culture of rural really solid people". 


\subsection{Data Collection and Analysis}

To effectively address the study objectives, this study utilized a qualitative case study research design [28]. Qualitative research is designed to open "new paths of thought" rather than verify a particular phenomenon [29]. It can provide insights into how people think about complex issues in a tourist destination, such as tourism resources and impacts, futures for tourism, and preferred tourism scenarios [30]. Interpretive research methods were utilized with the aim to collect rich and informed data. This included in-depth semi-structured individual interviews conducted within a two-month duration of fieldwork. Interviews were conducted with key informants representing a range of tourism-related organizations involved in destination marketing and management including the Convention and Visitors Bureau, Economic Development Authority, Cultural District Authority, local and county government, community foundation, private businesses, and non-profit organizations. Destination leadership or "key informants" are a critical stakeholder group in successfully developing rural destinations because the successful promotion of development and management planning requires more than usually informed, skilled and dedicated leadership [31].

Stakeholders were selected in an attempt to cover a diversity of perspectives throughout the county based on the researchers' knowledge of the local tourism industry and recommendations by board members of the Cultural District Authority. This technique yielded 30 interview candidates (see Table 2), which the authors believe to be a representative sampling frame. Interviews were recorded and the data were transcribed as soon as possible afterwards. Data collection and thematic analysis occurred concurrently, with early analysis informing later interview protocols. Data analysis included coding of the data to explore the themes generated in the field and to group different aspects of the data to compare emerging categories with those already unearthed in the literature, ensuring the selection of the most representative and inclusive categories. Data analysis was conducted using Nvivo 11 software.

Table 2. Interview candidates.

- President, Tucker County Cultural District Authority

- President, Artspring

- Owner, Canaan Realty

- Owner, Whitegrass Ski Touring Center

- Tucker County Commission, Development Director, Tucker Community Foundation, and Tucker County Cultural District Authority

- Owner, The Purple Fiddle

- Superintendent, Blackwater Falls State Park

- Executive Director, Tucker Community Foundation and Tucker County Cultural District Authority

- Superintendent, Canaan Valley National Wildlife Refuge

- Owner, Ben's Old Loom Barn

- Director, Tucker County Cultural District Authority

- Marketing Director, Tucker County Convention and Visitors Bureau

- Tucker County Planning Commission and Friends of the Blackwater

- Executive Director, Tucker County Convention and Visitors Bureau

- Heart of the Highlands and Friends of the 500th

- Timberline Four Seasons Resort

- Mayor, Town of Thomas

- Superintendent, Canaan Valley State Park

- CEO, Canaan Valley Resort

- Verglass Media

- Owner, Bright Morning Inn

- Owner, Hellbender's Burrito's

- Owner, Stumptown Ales

- Owner, Verglass Media

- Owner, Big Belly Deli

- Owner, Creature Gallery and the Whiteroom Gallery

- Buxton and Landstreet Gallery and Studios

- Owner, the Cooper House and the Billy Motel

- Owner, Three Castle Antiques

- Director, New Historic Thomas 


\section{Results and Discussion}

The key informant interviews revealed themes which included marketing and management challenges including addressing resident and visitor concerns for maintaining authenticity and sense of place while capitalizing on the improved accessibility of the destination; the need for economic diversification following the decline of extractive industries; coping with seasonality, low wage jobs, and lack of employees; connecting resorts to small businesses and communities; and establishing a common vision, identity, and coordination of activities. In addition to a better understanding of how stakeholders are addressing these significant challenges, the interviews identified numerous organizations involved in some aspect of destination marketing and management and allowed the researchers to conduct an audit of their roles and responsibilities and develop a destination management framework to guide the destination toward a more effective and coordinated management strategy. These specific challenges and the destination management framework are discussed in the following section.

\subsection{Rural Destination Management Challenges}

\subsubsection{Maintaining Authenticity and Sense of Place}

Consistent with the findings of multiple authors, maintaining authenticity was top of mind for many stakeholders with the completion of Corridor $\mathrm{H}$ cutting the driving time from Washington DC almost in half and with it the fear of the commercial development that often follows improved access $[10,11,17,18,20]$. One stakeholder commented, "I mean you can get here in a lot less time. The road is beautiful and I think as it progresses you're going to see numbers go up even more." Others noted that visitors are aware of keeping things authentic and that the uniqueness is the primary draw for visitors because people appreciate and want to experience the small shops and breweries and restaurants that are non-chain. One stakeholder emphasized that, "the closest McDonald's is $20 \mathrm{~min}$ away, there's no chain hotels and that's what makes us unique".

With accessibility comes hopes of more visitors and increased revenue but also fears of overdevelopment and commercialization. The recent completion of Corridor $\mathrm{H}$ has triggered many conversations and spurred many community groups to action to ensure that they maintain control of their destiny while harnessing the opportunity for economic development that improved access brings. With Washington, D.C. within a $3 \mathrm{~h}$ drive they are starting to see more day visitors which has the potential to increase revenue, yet there is concern about what the new highway is going to do for or to the area. With the development of second homes, the increased demand on the land, and the increased use of the hotel rooms and lodging rooms, one stakeholder emphasized that, "it's a very real conversation".

Stakeholders mentioned the importance of maintaining the authenticity as a key component to attract visitors who then want to relocate and become residents for the destinations unique qualities that they cannot find elsewhere, and which is key to making them want to become a permanent resident. One stakeholder commented that, "I think a lot of those people you know realize the importance of preserving that uniqueness of this area because that's what brought them here."

Stakeholders expressed concern about unleashed tourism and impacts they had seen in other destinations where in their opinion too much tourism ruined it to the point that they did not want to return and economic gain drove development not community interests. In their opinion, "there's nothing wrong with it [tourism development] unless you keep it under control and it doesn't turn into Disneyland, I think a lot of destinations have. That is the only thing that would concern me is uncontrolled growth." Another stakeholder commented, "we've seen other areas similar to us where the tourism has been uncontrolled and it just expands wildly and develops things that are not necessarily pro community, it might be pro tourists but not necessarily pro community".

Another stakeholder commented that a key to maintaining authenticity is the need to attract the right type of visitor, i.e., the cultural tourist, "I do think that the type of tourists I personally want to 
encourage are the stewards of the outdoors, people who are concerned about what they leave behind you know what sort of footprint they're making." This is the early stage of development recommended as an ideal destination stage appealing to Allocentric/Venturer types [32]. The ideal positioning on Plog's psychographic curve lies near the middle of the Near-Allocentric/Venturer segment of travelers where the destination usually has a reasonable level of development, but it has not gotten out of hand or lost its uniqueness. New wealth has improved the living conditions for local residents, however, planning and control is imperative at this stage because many unplanned destinations face a declining future because uncontrolled growth discourages venture-type travelers.

Zoning ordinances are one mechanism to control development. Canaan Valley established zoning regulations in the 1998 [33]. It is the only place in Tucker County that has had zoning regulations which includes guidelines about billboards, roadside signs, lighting, how close you can build to your neighbor, etc. Some residents resist any control or oversight of development. Some see zoning as a very evil thing but there has been a group of people across time who have recognized the importance of having some kind of plan to guide and control that growth so that it will happen in a way that is compatible with the area in order to "enhance it, not change it". Other stakeholders commented on the opportunity to develop regulations to manage growth, in order to "protect our natural assets and to manage growth in a way that benefits nature as well as the populace here from an economic standpoint, and even more importantly from a quality of life standpoint".

\subsubsection{Economic Diversification}

As Tucker County's economy transitions from one based solely on coal and timber extraction, local stakeholders expressed the need to focus on not only attracting tourists but also the opportunity to attract people to visit that may want to live and work in a rural community and help to diversity the economy. Those who visit that live in urban areas, come as tourists and often end up deciding to stay here because as one stakeholder noted, "that's where tourism is not just about what happens on memorial day weekend, it's about making people want to become part of the community."

For many years, the economy in this county was based on coal and timber. Now, many young people have to move away for employment opportunities. One stakeholder noted that tourism brings in diversity and can help turn around the brain drain by bringing in people with new ideas and with technology it's easier for people to relocate because "it's a secondary effect of bringing people here who know how to get into a more modern business climate you know the coal mining is gone here and that's a hard, hard pill to swallow".

Another stakeholder commented on the need to focus on the intrinsic qualities of the destination and the quality of life found in rural areas that can attract the right kind of people to become permanent residents. It is the connection with nature, clean air, clean water, healthy forests and a high quality of life that stakeholders felt will make people want to be there and with that bring their skill sets and possibly jobs. One commented that the focus for economic development needs to be on smaller scale entrepreneurs that want to live there for the intrinsic qualities that the county already has.

\subsubsection{Seasonality, Low-Wage Jobs, Lack of Employees}

Although the people, natural beauty, and rural setting have been attracting visitors and permanent residents, and Tucker County, WV is fortunate to have both summer and winter activities, numerous stakeholders commented that one of the biggest challenges in running a tourist business is the seasonality, since they can be just overwhelmed with people on certain weekends and then be very slow and that it is hard sometimes to keep employees motivated managing a business when there are visitors and money coming in some months and then there are months where there are few visitors and little revenue. One business owner commented that "when tourists are not traveling then it's really hard to survive until the next time the tourists come you got to be really good at planning ahead and saving for your future dry months". Other business owners commented that the growth that is projected should include more businesses that can sustain themselves on a year-round basis that 
somehow there has to be a mixture of businesses coming in that can stay open thereby bringing in more people at times that can feed off into the existing businesses.

Finding employees willing to work in tourism businesses is also a challenge since a lot of the jobs are fairly low-paying and seasonal which makes it very hard to get ahead and plan and support a family working in the tourism industry. Many have to work three different jobs at a time to get by. Others commented that the biggest downside to running a business is the lack of employees since it is a very rural area and very few people live there so finding people who want to work in tourism businesses that are seasonal and often low-wage is a big challenge. The resorts also commented on the challenge of finding employees to work not only the entry level positions but also the higher wage management positions.

\subsubsection{Connecting Resorts, Small Businesses, and Communities}

Small business owners discussed being actively engaged in sharing information and coordinating their activities so that they are not competing with the visitor's time but instead collectively trying to grow the customer base in Tucker County together and together creating a bigger attraction for Tucker County because as one local business owner noted, "we can't do it by ourselves and so we've got to cooperate in order to build that customer base together, because after all there is a limited amount of people that come to town on any given day and we want to share in those customers".

Though small business owners are cooperating to grow the customer base, some discussed the challenge of connecting their small businesses with visitors at the nearby state parks and resorts and encouraging visitors to leave the parks and visit lesser-known attractions in order to spread the economic impact of tourism throughout the county. The two resort state parks in the county serve as anchor attractions attracting thousands of visitors a year yet some in the community view the resorts as islands with walls that try to keep visitors within the confines of the resort to maximize visitor spending. However, state park leadership is working to be more collaborative and encouraging the other attractions in the community to benefit from them and vice versa through a collaborative relationship by reaching out and working with local business owners and trying to open doors to let the local community know how to cooperate and establish relationships. A state park superintendent discussed the opportunity he sees in partnering with other local attractions when he noted:

We do want to push our people out and go see these other places, if we were able to push them to let's say Thomas, they'd fall in love with that place. They'd fall in love with Davis. And they're just two cool towns with two different histories. Snowshoe is trying to artificially build what we already have here, which is a community. They have their village with shops and things. Well, we already have that except its natural and it's historic.

These statements are consistent with the findings of several authors that, due to the many disparate elements that comprise the tourism product, as Tucker County, WV matures as a tourism destination, it faces a critical need for these attractions to not work in silos and compete against one another but for greater coordination of activities and experiences, exchange of information, and use of synergies $[4,21]$.

\subsubsection{Vision, Unity, Collaboration, and an Identity}

The key informant interviews identified multiple organizations with a primary responsibility for destination marketing and management activities in addition to a number of supporting organizations and businesses. It was apparent that the stakeholders in Tucker County want to work together and that the competitive businesses, local municipalities, and community organizations realize that they are stronger if they collaborate.

Although there are many organizations actively trying to improve the destination, establishing a common vision and coordination of activities were key challenges discussed. While stakeholders agreed that the county is fortunate to have a lot of hard-working people with community organizations, non-profits, and volunteers actively engaged in promotion, community revitalization, art, trails, 
heritage, music, etc., one stakeholder noted that "it would be nice if an individual or an organization would take on that lead role as part of their business to coordinate an effort to pull us all together cohesively". This need for coordination is critical and consistent with Presenza and coworkers' determination [8] that an important assessment of the DMO ability to foster IDD will be directly related to the number and quality of relationships with tourism destination stakeholders and that without a sound core competency of stakeholder coordination, the DMO will not have a foundation for the other dimensions of IDD.

A common vision was also identified as missing and needed to guide the coordination. One stakeholder commented, "we've realized that there are many visions and many parallel visions of where Tucker County is going, so we are working on a more unified vision for where we're going". This is consistent with the findings of Ritchie and Crouch that tourism resources are likely to be used more effectively when the different modes of deployment share a common view regarding a destination's strategy for tourism development [4].

In addition to coordination and a common vision, more unity and collaboration amongst the communities and organizations was identified. According to one stakeholder, "there's a lot of things going on but there's not necessarily a unity to the whole thing". Key informants stressed the importance of bringing everyone to the table to have more dialogue about what is happening in various parts of the county so that "Davis knows what Thomas is doing, what Parsons is doing, what Hendricks is doing so that there's some continuity and consistency and some agreement that this is what's best not just for your community, but for the entire county". It was clear that the leadership recognized the importance of establishing this common vision, unity, and collaboration to sustainably manage the destination and that establishing a process to accomplish this was a considerable challenge that was evolving over time but that the process was being initiated and that they were actively encouraging everyone in the community to be part of that process as it develops.

Others commented on the need to establish an identity that represents these cultural assets. One stakeholder noted that Thomas's identity as an arts town was something that was purposefully done when some artists moved there and they decided that they wanted that to be there identity and they created that and it has brought in more artists. The Davis Renaissance group is working to be a unified voice so others recognize that they have a community they can make something of and is worth the state investing in. One stakeholder commented on the need to find that identity that can then lead to investments.

There's a small microcosm of everything that's happened in this country in this county and capturing that identity and then being able to present to the state to say we can be a little gem for you we just need the investment to smooth our edges.

\subsection{Destination Audit and Management Framework}

A key challenge with establishing this common vision, increased collaboration and unity, and managing a destination management process was identifying which organization would assume these activities as a core component of their mission. There are numerous organizations in the county with a role in tourism marketing and/or management. An audit of the role(s) of these organizations in destination marketing and managing, whereby the DMO compares the activities outlined in their model to what they currently do and searches for other organizations throughout the community that may partially or fully perform (or potentially perform) other activities was conducted in an attempt to develop a perceived management framework [8].

The Tucker County Convention \& Visitors Bureau's (CVB) mission is to support, sustain and assist in the growth of the tourism industry in the county. The main source of funding for the CVB is $50 \%$ of the hotel/motel occupancy tax collected throughout Tucker County. This $6 \%$ fee is collected from visitors staying 30 days or less in hotels, motels, vacations homes, condominiums and Bed and Breakfasts. According to the CVB's Executive Director, "more than 80 percent of our budget is spent on advertising Tucker County as a tourism destination encouraging people to come and spend a couple 
of days and enjoy all that Tucker County has to offer." In addition to staffing a visitor's center in downtown Davis, WV, advertising mediums include print media, earned media, social media, digital marketing, direct mail, radio, and consumer travel shows. The visitor's center provides services and information for guests to the area and is staffed by hospitality professionals. This is consistent with the findings of [2] that since the primary funding source for CVB's comes from the "bed" tax, most small town CVB's view their role as helping those businesses that collect the tax, e.g., putting "heads on beds", and not responsible for issues regarding tourism development.

Envisioning the potential impact the improved access might have on the county, and with the realization that an organization did not exist with the sole mission to protect the culture of the county, local residents proposed forming a Cultural District Authority. They realized that the Development Authority is instituted for industrial/commercial development and while they are involved in some tourism development they cannot do all of it and the CVB is designed for marketing of tourism and is limited in development work based on their bylaws and their funding source so no single organization is in place to develop the assets that could then be marketed. The purpose of the Cultural District Authority being formed was that local residents realized that there is a gap they needed to fill in order to preserve the culture for future generations.

The Tucker County Cultural District Authority (CDA) was authorized by the West Virginia Legislature in 2013 to plan and execute and ongoing and continuous program for the development and enhancement of artistic, cultural, historical and recreational attractions that will promote culture, education and tourism in Tucker County [34]. The CDA consists of seven board members who must be residents of Tucker County. One of the board members must be a county commissioner and the other six must demonstrate an interest in cultural tourism and be recommended by the County Commission and appointed by the Governor. Current board members include the President of the Convention and Visitors Bureau and the Executive Director of the Community Foundation. The CDA was able to leverage a small portion of the hotel-motel tax from the County Commission in order to provide mini-grants for tourism development projects.

A CDA board member discussed the role of the CDA in comparison to the other organizations in the county:

We're moving slowly through the process to establish ourselves, we need to understand our role, we need to make sure that we are engaged in all of the groups in the county who make up the culture of Tucker county, it goes everything from outdoor recreation to the historical attractions to the arts and crafts to the food, the farms, the coal mining so you know trying to embrace all of that and trying to capture it so that any visitor coming into this county understands the wealth of culture here, that's a daunting task.

The Tucker County Economic Development Authority's (TCEDA) mission is to encourage economic growth and opportunity in the area, to enhance and maintain economic development, and to preserve Tucker County's values and heritage [35]. Its role is to promote economic prosperity but also to retain and celebrate the county's cultural heritage and in doing so attract companies to Tucker County. Although EDA's in rural areas are often more focused on traditional forms of economic development like manufacturing, the TCEDA's role in tourism is evolving as tourism increasingly plays an important role in the economy of Tucker County. They support tourist based businesses by helping them develop strategic plans as well as getting them access to capital and helping them identify and even sometimes helping to interview some of their employees. They also try to make sure that there is a connection between local residents and tourist focused businesses because according to the TCEDA Executive Director, "that's how we make the soul of our community, is that the residents feel like they can also participate and be part of what these tourist businesses have to offer, and helping our tourist businesses be ambassadors for the rest of the community."

The Tucker County Commission administers programs and services for Tucker County, is led by 3 County Commissioners, and is home to five municipalities including Davis, Hambleton, Hendricks, 
Thomas, and Parsons [36]. A County Commissioner described the role of the Commission in tourism as being a good ambassador for the county, being united and welcoming to tourists to this county because "it's important to our economy, but it's also just important to have people like to come and play here and maybe they'll eventually stay here." The Tucker County Commission is actively involved in providing leadership, oversight, and funding for tourism marketing and management.

The Tucker Community Foundation (TCF) is a public charity that serves eight counties in North Central West Virginia and Garrett County, MD. Since the organization was formed in 1989, it has granted more than $\$ 6$ million to support local initiatives many of these initiatives supporting the growth of the tourism industry. Current projects include the Tucker Boulder Park, and RUN FOR IT, an annual $2 \mathrm{k} / 5 \mathrm{k}$ that provides a large cash purse for non-profit community causes [37]. According to the TCF Development Director, "to witness the impact of local philanthropy and when you see how everyone through this whole region has gotten engaged in local philanthropy, to have that kind of grass roots support is quite amazing." As a CDA partner, the Tucker Community Foundation is instrumental in obtaining grants and distributing funds for tourism projects.

While numerous organizations have been formed to focus on specific niche opportunities in order to support growth in targeted areas such as art and trails, this has spurred the need for coordination of activities across the county. Artspring is an organization as well as a festival founded in 2011 and dedicated to supporting the art community by providing services to them, and making sure that the general public sees the benefit of that in the community and appreciates it and is proud of it. The role of the organization is to be concerned about the roles that the arts play in economic development and tourism because as described by the executive director, "we believe it's the arts that people will see as a reason to come here, and that will be a key piece of the economic development of the area".

Blackwater Bike Association is committed to establishing an outdoor recreation based community with a core of mountain bikers who have established a local chapter of the International Mountain Biking Association that are establishing the relationships with the local landowners and establishing the relationships with the business owners in trying to propel mountain biking so that it can grow. According to one board member, "we just like riding our bikes we just want people here to enjoy what we do that's really what it comes down to". The chapter organizes the Canaan Mountain Bike festival in June each year.

Friends of the 500th is a volunteer group supporting the Canaan Valley National Wildlife Refuge. Canaan Valley National Wildlife Refuge uses the group to advocate for habitat management for outreach for supplemental income. The Friends' mission is to support the refuge, to insure public use and public access to public lands, and within that, it is protecting natural and cultural resources, and providing environmental education opportunities.

Heart of the Highlands mission is to connect the trails that exist on all the public lands in Tucker County and be able to present the trail system as a whole instead of as multiple parts and to get the public land managers to be able to work together and meet some of the other stakeholder needs that have been identified. According to the organization's project administrator, "everybody is receptive to the idea and we've been able to make some giant strides forward in working together and reaching ideas and plans that everybody can be receptive to and fully support".

In addition to niche tourism organizations, community revitalization groups have formed to focus on specific opportunities within communities and downtown revitalization where infrastructure built to support extractive industries is being repurposed to provide services to visitors. The New Historic Thomas organization is a nonprofit community organization that was founded in the 1990s as a group of volunteers that really care about the community and want to see the downtown revitalized. Their goal is to encourage visitors and residents to stay in Thomas all day and visit galleries and the eateries and then go hop on the trails. According to the Mayor of Thomas, "we're very lucky to have a nice group of young people who really like where they are and are making a contribution towards where they are". 
The Davis Renaissance committee's primary goal is to help beautify and make the town of Davis a little more attractive and a little more curb appeal and make the community a little more vibrant and have a collective uniform look throughout the town to make it look a little more welcoming. According to one board member, "Davis Renaissance is about trying to develop a community identity where people come to a place not just driving through a bunch of buildings and streets but there's actually a community there".

Although Tucker County is fortunate to have these organizations and businesses committed to sustainable development of the destination, a destination management framework was lacking, thus the authors developed a perceived destination management framework based on the outcomes of the stakeholder analysis in order to define a structure for the roles and responsibilities for destination marketing and management activities. Following a participatory planning and design process facilitated by West Virginia University faculty, the Cultural District Authority developed a performance agenda which includes coordinating management activities under five primary goals for cultural tourism development-protect, connect, enhance, promote, and monitor cultural assets. Implementation of the priority activities identified for each of these goals will be coordinated through the stakeholder network. The perceived destination management framework is presented in Figure 4 and represents a clear separation of marketing and management roles and responsibilities for the CVB and CDA in hopes that this destination can create a destination management culture that can cope with the decentralized, multi-player, multi-stakeholder nature of the rural tourism business [1].

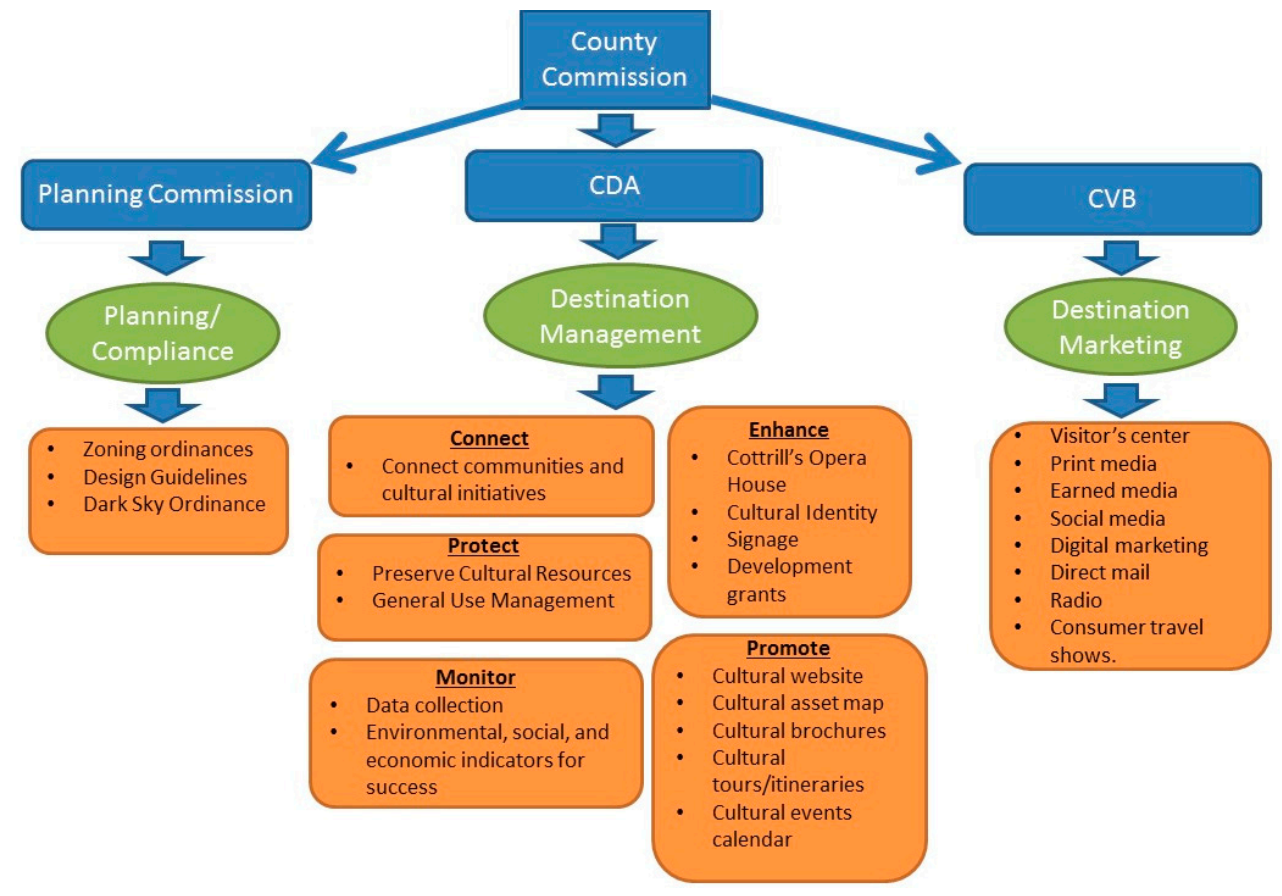

Figure 4. Tucker county perceived destination management framework.

\section{Conclusions and Implications}

This study has practical implications for rural destinations and expands upon the body of research on the role of DMOs in rural destinations and the challenges they face. This is one of few studies that have identified the need for separate organizations to assume marketing and management roles. While Presenza et al. [8] encourage DMOs to engage in a combination of marketing and product development and management, this study makes a novel contribution to the literature since the destination audit of Tucker County, WV revealed the need for a new organization with a specific mission to sustainably develop and manage tourism and coordinate activities of the stakeholder network. While the CVB is actively engaged and funded to fulfill the EDM activities of the Presenza et al. [8] destination 
management model, as described in Table 1, it was clear that they did not view the IDD function as their responsibility or core to their mission. Stakeholders confirmed this and, instead of urging the CVB to assume IDD activities as recommended by Presenza et al. [8], they stressed the need for a new entity to assume this role. This new entity, the Cultural District Authority, formed locally by concerned stakeholders anticipating improved accessibility from metropolitan areas, is being structured to assume the core component of the IDD model of cooperation, coordination, and partnerships among local stakeholders.

After the CDA establishes a sound core competency of stakeholder coordination, members of the stakeholder network are positioned to support the foundation for IDD efforts including quality of the visitor experience (CVB/CDA), visitor servicing (CVB), human resources development (County Commission/CDA/Development Authority), resource stewardship (CDA/Planning Commission), information/research (CDA/West Virginia University), and finance and venture capital (CDA/Community Foundation/Development Authority).

Although a consistent source of funding exists for destination marketing through the hotel-motel tax, destination leadership is challenged to find funding needed to support destination management activities since there are currently very few funding streams from the state dedicated to tourism development and no local or county tax designed to fund tourism development projects. This is consistent with the findings of Pike and Page [6] that very few DMOs have either the mandate or resources to effectively manage their destination. While a precise legislative or political framework was established to guide the Cultural District Authority, the legislation does not include state funding for development and management, thus, securing internal and external funding for these activities will be critical since long-term financial and technical support is essential if tourism is to play an effective rural development role [13].

While this study has shed new light on destination marketing and management roles, challenges identified for rural tourism identified in this study were consistent with those found in the literature, including maintaining authenticity and sense of place [10,11,18-20,30]; staffing and quality personnel [12]; seasonality [13]; pursuing target markets that minimize negative tourism impact and appreciate the uniqueness of the region [11]; coordination, cooperation, and partnerships among businesspersons, local leadership, and rural tourism entrepreneurs [9,10,22,23]; respect for local residents and positive economic impact for the community [11]; and economic diversification [10].

This study explores the challenges of sustainably developing tourism in a rural destination at the development stage of the Tourism Lifecycle [7] and the potential role for a newly formed destination management organization. It is apparent that stakeholders are proactively trying to resist the development stage pressures of resident dissent for tourists, commercialization, and loss of authenticity described by Plog [38] as "many destinations follow a typical pattern of uncontrolled tourism development ... losing their distinctive character along the way and with the greater number of these attractions the greater probability that they will never go away and will contribute to the decline of the area". While this destination appears to have taken control of its destiny, it faces considerable challenges in achieving its goals.

Stakeholders are optimistic and actively engaged in creating and managing what could become a model destination for rural destination management. One stakeholder summarized her perspective about the people and the process underway in Tucker County, WV.

I see opportunities but I also see the challenges, I think we're on the right path, I think that no matter

how we agree or disagree, that in the end, we're going to make decisions that are best for the county, not just for us individually, and so I trust that about the people here.

\section{Limitations and Future Studies}

This study is not without its limitations. While this study revealed a clear delineation of destination marketing and management activities and a perceived destination management framework, additional research to apply the destination management model to other rural destinations should 
be conducted to determine if this delineation is consistent in other destinations or if marketing and management activities are combined activities of a rural DMO as suggested by the literature. Additional research is necessary to further define the structure of the CDA, engage additional stakeholders, and document achievements of the destination management goals over time and determine whether stakeholder roles and activities are consistent or change over time as the destination continues through the stages of the Tourism Lifecycle [7].

Timur and Getz [38] suggest that integrating stakeholder and network theories provide a robust foundation for identifying critical stakeholders in destination development, for determining whether identified critical stakeholders have existing relationships with the other members of destination networks and for identifying those organizational stakeholders who should lead in establishing tourism stakeholder networks. Social network analysis can be used to identify "nodes", or "actors", which are entities, persons, organizations, or events; "links", which are the relationships of any kind between the actors; "networks", which are the patterns formed from the combination of all the actors and links within the system; "density", which is the number of connections between actors within the network; and "centrality". Presenza et al. [8] suggest that an important assessment of the DMO ability to foster IDD will be directly related to the number and quality of relationships with tourism destination stakeholders and to conduct network analyses to determine the strength of the DMO's position (centrality) in the network vis-à-vis the density of the network.

While this study has shed some light on the number of organizations and their role(s) related to destination management, social network analysis would determine the type and strength of the relationships within the perceived destination management framework. The organizations identified as having a role to play in the network that were identified in this study and should be included in the network analysis are listed in Table 3. Additional analysis to further define the structure of the destination management network including the actors, links, density, and centrality would be a logical next step in guiding the stakeholders of Tucker County, WV toward their vision for sustainable rural tourism. 
Table 3. Stakeholder map.

\begin{tabular}{|c|c|c|c|c|c|c|c|}
\hline $\begin{array}{c}\text { Destination } \\
\text { Management/Marketing }\end{array}$ & Planning & Communities & Recreation & Arts & Entrepreneurship & Agriculture & Heritage \\
\hline $\begin{array}{l}\text { Convention and Visitors Bureau } \\
\text { Cultural District Authority } \\
\text { Planning Commission }\end{array}$ & $\begin{array}{l}\text { Community } \\
\text { Foundation } \\
\text { Development } \\
\text { Authority } \\
\text { Municipalities } \\
\text { Parks \& Recreation } \\
\text { Building Commission } \\
\text { Canaan Valley } \\
\text { Zoning Board }\end{array}$ & $\begin{array}{l}\text { PRO OnTRAC } \\
\text { Davis Renaissance } \\
\text { New Historic } \\
\text { Thomas } \\
\text { Hendricks- } \\
\text { Hambleton } \\
\text { Canaan Valley }\end{array}$ & $\begin{array}{l}\text { Heart of the Highlands } \\
\text { US Forest Service } \\
\text { National Youth Science } \\
\text { Foundation } \\
\text { Department of Natural } \\
\text { Resources } \\
\text { Canaan Valley Resort } \\
\text { Blackwater Falls State Park } \\
\text { New Historic Thomas } \\
\text { Blackwater Bike Assoc. } \\
\text { Friends of the Blackwater } \\
\text { Parks \& Rec Boards }\end{array}$ & $\begin{array}{l}\text { ArtSpring } \\
\text { StART }\end{array}$ & $\begin{array}{l}\text { Development Authority } \\
\text { Eastern Community } \\
\text { College } \\
\text { WVU Launch Lab }\end{array}$ & $\begin{array}{l}\text { Food \& Farm } \\
\text { Initiative }\end{array}$ & $\begin{array}{l}\text { Historic Landmark } \\
\text { Commission } \\
\text { Historical Society } \\
\text { Alpine Heritage } \\
\text { Preservation } \\
\text { Friends of the Blackwater } \\
\text { Appalachian Forest } \\
\text { Heritage Association }\end{array}$ \\
\hline
\end{tabular}


Acknowledgments: This study was made possible through a grant from the Claude Worthington Benedum Foundation.

Author Contributions: Doug Arbogast, Jinyang Deng, and Kudzayi Maumbe conceived and designed the experiments; Doug Arbogast performed the experiments; Doug Arbogast analyzed the data; Doug Arbogast contributed reagents/materials/analysis tools; Doug Arbogast wrote the paper; Jinyang Deng and Kudzayi Maumbe reviewed and offered recommendations for improvement of the manuscript prior to submission.

Conflicts of Interest: The authors declare no conflict of interest.

\section{References}

1. Lane, B.; Kastenholz, E. Rural tourism: The evolution of practice and research approaches-Towards a new generation concept? Tourism 2015, 23, 1133-1156. [CrossRef]

2. Gartner, W. Rural tourism development in the USA. Int. J. Tour. Res. 2004, 6, 151-164. [CrossRef]

3. Gartrell, R. Strategic partnerships. In Destination Marketing for Convention and Visitor Bureaus, 2nd ed.; Kendall/Hunt Publishing Co.: Dubuque, IA, USA, 1994; pp. 230-232.

4. Ritchie, J.B.; Crouch, G.I. The Competitive Destination: A Sustainable Tourism Perspective; CABI: Wallingford, UK, 2003.

5. Dore, L.; Crouch, G.I. Promoting destinations: An exploratory study of publicity programs used by national tourism organizations. J. Vacat. Mark. 2003, 9, 137-151. [CrossRef]

6. Pike, S.; Page, S.J. Destination Marketing Organizations and destination marketing: A narrative analysis of the literature. Tour. Manag. 2014, 41, 202-227. [CrossRef]

7. Butler, R.W. The concept of a tourist area cycle of evolution: Implications for management of resources. Can. Geogr. 1980, 24, 5-12. [CrossRef]

8. Presenza, A.; Sheehan, L.; Ritchie, J.B. Towards a model of the roles and activities of destination management organizations. J. Hosp. Tour. Leis. Sci. 2005, 3, 1-16.

9. Wilson, S.; Fesenmaier, D.R.; Fesenmaier, J.; Van Es, J.C. Factors for Success in Rural Tourism Development. J. Travel Res. 2001, 40, 132-138. [CrossRef]

10. The University of Minnesota Extension Service. Rural Tourism Development Training Guide; The University of Minnesota Extension Service: Willmar, MN, USA, 1991.

11. McGehee, N.G.; Boley, B.B.; Hallo, J.C.; McGee, J.A.; Norman, W.; Oh, C.O.; Goetcheus, C. Doing sustainability: An application of an inter-disciplinary and mixed-method approach to a regional sustainable tourism project. Tourism 2013, 21, 355-375. [CrossRef]

12. Bornhorst, T.; Ritchie, J.B.; Sheehan, L. Determinants of tourism success for DMOs \& destinations: An empirical examination of stakeholders' perspectives. Tour. Manag. 2010, 31, 572-589.

13. Sharpley, R. Rural tourism and the challenge of tourism diversification: The case of Cyprus. Tour. Manag. 2002, 23, 233-244. [CrossRef]

14. Gannon, A. Rural tourism as a factor in rural community economic development for economies in transition. Tourism 1994, 2, 51-60. [CrossRef]

15. Fleischer, A.; Felsenstein, D. Support for rural tourism: Does it make a difference? Ann. Tour. Res. 2000, 27, 1007-1024. [CrossRef]

16. Fleischer, A.; Pizam, A. Rural tourism in Israel. Tour. Manag. 1997, 18, 367-372. [CrossRef]

17. Bramwell, B. Rural tourism and sustainable rural tourism. Tourism 1994, 2, 1-6. [CrossRef]

18. George, E.W.; Mair, H. Rural Tourism Development: Localism and Cultural Change; Channel View Publications: Bristol, UK, 2009; Volume 17.

19. Plog, S.C. Why destination areas rise and fall in popularity. Cornell Hotel Restaur. Adm. Q. 1974, 14, 55-58. [CrossRef]

20. Rosenow, J.E.; Pulsipher, G.L. Tourism the Good, the Bad, and the Ugly; Century Three Press: Lincoln, NE, USA, 1979.

21. Volgger, M.; Pechlaner, H. Requirements for destination management organizations in destination governance: Understanding DMO success. Tour. Manag. 2014, 41, 64-75. [CrossRef]

22. Holden, A. Exploring stakeholders' perceptions of sustainable tourism development in the Annapurna conservation area: Issues and challenge. Tour. Hosp. Plan. Dev. 2010, 7, 337-351. [CrossRef] 
23. Pasape, L.; Anderson, W.; Lindi, G. Towards sustainable ecotourism through stakeholder collaborations in Tanzania. J. Tour. Res. Hosp. 2013. [CrossRef]

24. Beritelli, P.; Bieger, T.; Laesser, C. The New Frontiers of Destination Management: Applying Variable Geometry as a Function-Based Approach. J. Travel Res. 2014, 4, 403-417. [CrossRef]

25. Pearce, D. Destination management in New Zealand: Structures and functions. J. Destin. Mark. Manag. 2015, 4, 1-12. [CrossRef]

26. United States Census Bureau. Quick Facts Tucker County, West Virginia. Available online: http://www. census.gov/quickfacts/table/PST045215/54093,00 (accessed on 31 August 2017).

27. Dean Runyan Associates. West Virginia Travel Impacts 2000-2014p. 2015. Available online: http://www. deanrunyan.com/doc_library/WVImp.pdf (accessed on 27 September 2017).

28. Yin, R. Case Study Research: Design and Methods; Sage: Beverly Hills, CA, USA, 2014.

29. Talburt, S. Ethnographic responsibility without the "real". J. High. Educ. 2004, 75, 80-103. [CrossRef]

30. Yuksel, F.; Bramwell, B.; Yuksel, A. Stakeholder interviews and tourism planning at Pamukkale, Turkey. Tour. Manag. 1999, 20, 351-360. [CrossRef]

31. Organization for Economic Cooperation and Development. Tourism Strategies and Rural Development. 1994. Available online: http:/ / www.oecd.org/cfe/tourism/2755218.pdf (accessed on 31 August 2017).

32. Plog, S. Why destination areas rise and fall in popularity. Cornell Hotel Restaur. Adm. Q. 2001, 42, 13-24. [CrossRef]

33. Canaan Valley Zoning Ordinance. 1998. Available online: http://tuckercountycommission.com/wpcontent/uploads/2016/05/Canaan-Valley-Zoning-Ordinance.pdf (accessed on 31 August 2017).

34. WVSB561. Tucker County Cultural District Authority. Available online: http://www.legis.state. wv.us /bill_status/bills_text.cfm?billdoc=sb561\%20intr.htm\&yr=2013\&sesstype=RS\&i=561 (accessed on 31 August 2017).

35. Our Mission. Tucker County Development Authority (TCDA). 2012. Available online: http://www.tuckerwv. com/about/ (accessed on 31 August 2017).

36. Tucker County Commission. Welcome to the Tucker County Commission. Available online: http:// tuckercountycommission.com/ (accessed on 31 August 2017).

37. About TCF. The Tucker Community Foundation. 2015. Available online: http://www.tuckerfoundation.net/ (accessed on 31 August 2017).

38. Timur, S.; Getz, D. A network perspective on managing stakeholders for sustainable urban tourism. Int. J. Contemp. Hosp. Manag. 2008, 20, 445-461. [CrossRef] 